\title{
Pengaruh Faktor Sosial Ekonomi terhadap Perilaku Kriminalitas (Tinjauan Literatur)
}

\author{
Sandy Adri ${ }^{\mathrm{a}}$, Syafruddin Karimi ${ }^{\mathrm{b}}$, Indrawari ${ }^{\mathrm{c}}$ \\ ${ }^{a b c}$ Universitas Andalas, Padang, Sumatera Barat, Indonesia
}

\section{INFORMASI ARTIKEL}

\section{Article history:}

Dikirim tanggal: 11 April 2019

Revisi pertama tanggal: 26 Juni 2019

Diterima tanggal: 30 Juli 2019

Tersedia online tanggal: 15 Agustus 2019

Keywords: socio-economic, crime economy, crime prevention

\section{ABSTRACT}

This article reviews a number of factors underlying personal motives to commit crime in order to reveal some socio-economic characteristics attributed with criminal behaviours. It would be beneficial to clarify the spheres in which the state may interfere to prevent and overcome crime actions with a correct knowledge to surpress the tendencies of certain social groups to commit crime or be criminalized. The state has been resolving crime issues by adding police officers, prosecutors and prison cells to ensure punishment. However, proper education along with the enhancement of its resources are now urgent to improve legal awareness which is the essential key of crime prevention. In the end, the criminology perpective on criminal behaviours remains complex since more information on subject's background and history need to be elaborated. A uniform treatment for diverse socio-economic situation is absurd while improving family and environmental wellbeings seem to promise reduction of individual tendency against the law.

\section{INTISARI}

Artikel ini mengulas faktor-faktor yang melatarbelakangi seseorang melakukan tidak kriminal. Kondisi sosial ekonomi seseorang diyakini mempengaruhi perilaku melawan hukum tersebut. Penulisan dirasa penting untuk mengetahui faktor yang memungkinkan untuk memberikan masukan pada pengambil kebijakan dalam mencegah dan menanggulangi tindak kriminal. Sehingga masyarakat atau kelompok masyarakat dapat terhindar dari perilaku kriminal atau dikriminalisasi. Dalam merespon fenomena kriminalitas negara telah berupaya dengan menambah petugas polisi, jaksa, dan sel penjara untuk memberikan hukuman bagi pelaku kejahatan. Upaya mereduksi kriminalitas dengan menambahkan guru dan meningkatkan sumber daya pendidikan merupakan langkah tepat untuk menciptakan masyarakat yang sadar hukum. Pada akhirnya, sudut pandang kriminologi dalam kajian perilaku masyarakat sangatlah kompleks. Banyak faktor dan latar belakang pelaku yang perlu diungkap sehingga diketahui karateristiknya terhadap peluang melakukan tindak kriminalitas. Menyeragamkan kondisi sosial ekonomi setiap individu menjadi suatu tindakan absurd. Memperbaiki kondisi sosial ekonomi, keluarga dan lingkungan adalah sebuah keniscayaan untuk menekan kemungkinan seseorang bertindak melawan hukum. 


\section{Pendahuluan}

Sejak Tahun 2000 hingga 2016, risiko masyarakat terkena tindak kriminalitas makin tinggi dan selang waktu terjadi tindak kriminalitas (crime clock) itu makin singkat. Tahun 2000 setiap 3 menit 2 detik terjadi satu tindak kriminal di Indonesia. Selang waktu terjadinya kejahatan meningkat signifikan Tahun 2016 menjadi 1 menit 28 detik terjadi satu kejahatan di bumi Indonesia (Paramita, 2018). Tindak kejahatan merupakan beban pembangunan. Sudut pandang ekonomi, efisiensi biaya kejahatan, maka kejahatan akan lebih baik untuk dicegah daripada membiarkannya terjadi untuk diberantas kemudian.

Salah satu upaya untuk mencegah terjadinya kejahatan adalah dengan melakukan suatu studi atau penelitian mengenai trend kejahatan dan faktor-faktor yang mempengaruhinya. Menurut Gwynn Nettler dalam bukunya "Explaining Crime", perhitungan dan pendataan terhadap kejahatan perlu dilakukan dengan sejumlah alasan penting (Nettler, 1984). Diantaranya, mengukur resiko kejahatan baik sebagai korban maupun sebagai pelaku. Alasan penting lainnya adalah mengevaluasi program-program penyelesaian maupun pencegahan kehatan yang diterapkan sebelumnya.

Ditinjau dari aspek ekonomi, Posner (1992) berpendapat bahwa tindak kriminal analog dengan inefisiensi dari perilaku anggota masyarakat. Konsep inefisiensi Posner tentang perilaku masyarakat melakukan pelanggaran pidana sejalan dengan pendapat para ahli ekonomi, bahwa sanksi (hukum) sama dengan harga (price) dari pelanggaran pidana tersebut.

Secara konkrit, anggota masyarakat memberikan sanksi sebagai respon terhadap perilaku kriminalitas sama dengan respon mereka terhadap perubahan harga (Sullivan, 2009). Ekonomi dalam kajian kriminal merupakan serangkaian perangkat, bukan hanya subjek. Hal ini menunjukkan tidak ada satu subjek pun meskipun tidak biasa, berada diluar jangkauan ekonomi (Levitt \& Dubner, 2005). Meski ilmu ekonomi bukan kerangka kerja yang sempurna dalam memandang dunia, namun ilmu ekonomi merupakan metode terbaik yang tersedia untuk menentukan cara mempengaruhi orang dan cara meramalkan perilaku mereka, termasuk tindakan kriminal (Conway, 2009).

Masyarakat secara rasional akan memberikan reaksi terhadap sanksi yang berat dengan menghindari atau mencegah untuk melakukan perbuatan kriminal atau melanggar hukum (Atmasasmita \& Wibowo, 2016). Realitasnya terbalik jika melihat pada kondisi kriminalitas di Indonesia meski kecenderungan menghindar atau menghindari perilaku kriminalitas lebih dominan. Berdasarkan data statistik kriminalitas yang dikeluarkan BPS (2018), maka dapat diketahui bahwa trend kriminalitas di Indonesia naik. Ditinjau dari jumlah laporan masyarakat pada pihak kepolisian, terjadi peningkatan dari 4.464 laporan di Tahun 2000 meningkat menjadi 14.921 laporan di Tahun 2016. Setelah mengkonversi laporan tersebut per 100 ribu penduduk, secara statistik diperoleh tingkat kejahatan per 100 ribu penduduk. Pada Tahun 2000 diketahui terjadi 84 tindak kejahatan per 100 ribu penduduk. Meningkat signifikan hingga dua kali lipat pada Tahun 2016 menjadi 140 tindak kejahatan per 100 ribu penduduk.

Penelitian Goulas \& Zervoyianni menyebutkan tindak kejahatan relatif tidak berbahaya jika diikuti dengan kondisi ekonomi yang memuaskan. Memuaskan dalam sudut pandang penelitian ini, ditandai dengan meningkatnya perekonomian. Konkritnya, kondisi memuaskan adalah ketika rasio ketenagakerjaan penduduk berada di atas rata-rata dan harapan hidup semakin membaik. Status sosial ekonomi yang mendorong perilaku kriminalitas juga diungkapkan Grover (2008). Menurut Grover, 67\% dari penghuni penjara di Britania Raya adalah pengangguran terbuka dalam tempo empat minggu. Masih dalam penelitian serupa, $48 \%$ dari narapidana memiliki sejarah hutang yang tidak mampu mereka lunasi.

Banyak kerugian akibat tindakan melawan hukum, sebagaimana kerugian akibat perilaku inefisiensi (Ramadhan, 2016). Mulai dari kerugian ekonomi, fisik, moral hingga psikologis. Dalam kacamata ekonomi, kriminalitas menimbulkan kerugian dengan adanya biaya yang harus dikeluarkan akibat dari tindakan tersebut. Pemahaman kita tentang kejahatan dan penyebabnya dapat ditingkatkan dengan mempertimbangkan faktor pendorong yang lebih jauh dari perilaku kriminal, sebuah analisis yang jarang ditemui (Durrant \& Ward, 2015).

Penelitian Goulas \& Zervoyianni (2015) yang dilakukan pada 25 negara Uni-Eropa dan Jepang, menyimpulkan negara diperkirakan mampu meningkat pertumbuhan pendapatan per kapita pendudukannya sekitar $1 \%$ per tahun jika mampu menekan tingkat kriminalitas sebesar 10\%. Di Indonesia kondisi ini akan dapat diamati jika asupan data statistik kriminalitasnya tidak bias. Hanya saja, statistik kriminalitas di Indonesia dan kebanyakan negara berkembang diambil dari laporan korban kejahatan pada pihak kepolisian saja. Apakah laporan tersebut terbukti sebuah tindak kriminal dan pelakunya benar sebagai terpidana validitasnya sulit dipastikan.

Menganalisis kriminalitas dengan variabel-variabel ekonomi menghadapi kerumitan. Namun, untuk variabelvariabel makro ekonomi dan regional sudah dilakukan di Indonesia. Penelitian (Sulistyo, 2014), menemukan bahwa tingkat kemiskinan berpengaruh positif terhadap tingkat kriminalitas di Indonesia. Faktor pengangguran dan tingkat kemahalan (inflasi) tidak berpengaruh terhadap tingkat kriminalitas di Indonesia. Dalam rentang waktu penelitian yang lebih lama di Pakistan, 
kriminalitas disebabkan oleh pengangguran, kemiskinan dan inflasi (Gillani, Rehman, \& Gil, 2009).

Berperilaku kriminal tentu bukan pilihan tepat. Selain dianggap irrasional, faktor pendorongnya perlu dipahami untuk menghasilkan tindakan preventif dan komprehensif. Dalam teori kriminologi, hampir semua faktor yang mempengaruhi perilaku kriminal terkait kondisi sosial ekonomi individu pelakunya (Miller, 2009). Diluar itu, pengaruh lingkungan dan kebijakan, kelainan kejiwaan atau gangguan kesehatan mental diyakini Miller adalah pemicu utama dari perilaku kriminalitas di Abad 21. Tulisan ini bertujuan untuk membahas faktor sosial ekonomi pelaku kriminal, sehingga dapat ditemukan titik temu antara faktor yang mempengaruhi untuk ditanggulangi.

Penulisan artikel ini merangkum analisis dan sintesis dari literatur yang relevan tentang faktor sosial ekonomi yang mempengaruhi perilaku kriminal. Penulisan artikel dengan metode literature review tentang sosial ekonomi dan kriminalitas sudah dikaji sejak lama. Namun, motif dan jenis tindak kriminal yang fenomena makin adaptif dengan kondisi lingkungan serta individu pelaku, perlu diketahui untuk mendapatkan referensi untuk pencegahan kriminalitas yang lebih efektif.

\section{Pembahasan}

Seringkali kita lihat, seorang pelaku tindak kriminal masih nekad beraksi dengan risiko nyawa. Hal ini menguatkan temuan Quetelet (1796-1829) ahli ilmu pasti dan sosiologi asal Belgia; yang pertama kali menerapkan statistik dalam pengamatannya tentang kejahatan. Ia menyimpulkan bahwa orang tidak mempedulikan hukum pidana bahkan risiko terhadap dirinya untuk memenuhi kebutuhannya. Untuk itu, kejahatan dapat diberantas dengan memperbaiki tingkat kehidupan manusia (Santoso \& Zulfa, 2016).

Pendekatan ekonomi dalam mengkaji kriminalitas didorong keputusan pelaku mendapatkan biaya dan manfaat atas tindak kejahatan sebagai insentifnya. Sebagai respon, kita dan negara berupaya menekan kejahatan dengan menambah petugas polisi, jaksa, dan sel penjara untuk memastikan hukuman seberat-beratnya bagi pelaku kejahatan. Menanggulangi kejahatan juga dilakukan dengan menambahkan guru dan sumber daya pendidikan lainnya guna mengubah anak-anak putus sekolah menjadi lulusan sekolah menengah yang cenderung menjauhi tindak kejahatan karena memiliki kesadaran hukum yang lebih baik. Meskipun lingkungan yang bebas dari kejahatan terdengar menarik, seberapa besar pengorbanan untuk mendapatkannya? Bahkan untuk mencegah beberapa jenis kejahatan malah lebih mahal daripada harus mengalaminya. Sebuah pilihan sulit untuk menentukan seberapa batasan banyak kejahatan yang diizinkan (Sullivan, 2009).
Pandangan tentang kriminalitas memiliki sejarah panjang. Cesare Lombroso (1835-1909), yang sering disebut Bapak Kriminologi Modern; berpendapat bahwa penjahat adalah "atavistic" lahir berbeda dari orang lain, bahkan dibedakan oleh fitur fisik mereka. Buah pikiran Lombroso tersingkir meski beberapa fitur yang relatif permanen, baik genetik ataupun lingkungan diperoleh, mempengaruhi orang untuk melakukan kejahatan (O'Flaherty \& Sethi, 2014). Sosial ekonomi merupakan kedudukan atau posisi seseorang dalam kelompok manusia yang ditentukan oleh jenis aktivitas ekonomi, pendapatan, tingkat pendidikan, usia, jenis rumah tinggal, dan kekayaan yang dimiliki (Abdulsyani, 1994).

Banyak faktor sosial ekonomi yang berpengaruh terhadap perilaku kriminalitas. Pendidikan salah satunya. Faktor tingkat pendidikan diharapakan mengurangi perilaku kriminal dengan meningkatkan peluang mendapatkan pekerjaan yang legal. Sullivan (2009) menyebutkan, lulusan perguruan tinggi setidaknya berpenghasilan hampir dua kali lipat dari lulusan sekolah menengah atas dan lulusan sekolah menengah mendapatkan hampir 1,5 kali lebih banyak daripada mereka yang putus sekolah. Hubungan antara pendidikan dan kejahatan adalah premi kelulusan atau tingkat pengembalian pendidikan. Kelulusan meningkatkan upah, dan upah yang lebih baik mereduksi kriminalitas. Mengingat besarnya premi kelulusan (50 persen) dan elastisitas kejahatan yang besar sehubungan dengan upah (- 1,0 hingga -2,0), kebijakan pendidikan berpotensi menjadi kebijakan anti-kriminalitas yang manjur (Sullivan, 2009).

Dalam penelitian yang dilakukan oleh Lochner \& Moretti (2004) ada hubungan negatif antara tingkat pendidikan dan tingkat kejahatan. Penelitian tersebut menunjukkan penurunan kriminal disebabkan oleh perubahan perilaku kriminal dan bukan perbedaan dalam probabilitas penangkapan atau penahanan yang tergantung pada jenis kejahatan. Mereka memperkirakan investasi kelulusan sekolah menengah (untuk pria) mengurangi tindak kriminal sekitar 14-26 persen. Dalam penelitian lain, ditemukan tingkat pendidikan pelaku property crime lebih tinggi dibandingkan violent crime. Secara umum, dalam penelitian tersebut ditemukan bahwa pendidikan setara SMA mengurangi partisipasi pada violent crime sebesar $9 \%$ dan $10 \%$ pada property crime (Lochner, 2004).

Jonck et al., (2015) mendapatkan efek pendidikan terhadap kriminalitas berdasarkan ras di Afrika Selatan. Pada ras kulit putih, efek pendidikan menyerupai kurva "U". Dimana, pada tingkat pendidikan rendah dan tinggi, probabilitas melakukan tindak kriminalitas adalah tinggi. Selain pendidikan formal, life-skill (keterampilan) juga mempengaruhi perilaku kriminalitas. Bahkan, keterampilan tepat guna tersebut mampu merehabilitasi pelaku tindak pidana (Mohammed \& Mohamed, 2015). 
Dalam penelitian tersebut ditemukan fakta bahwa narapidana yang mengikuti program pendidikan saat dipenjara peluang melakukan kembali tindak kriminalnya lebih rendah daripada mereka yang tidak mengikuti program pendidikan keterampilan. Artinya, narapidana yang apatis dengan program pendidikan dipenjara, cenderung untuk mengulang tindak kriminal

Eide, Rubin, \& Shepherd (2006) menulis tentang tidak adanya hubungan sistematis antara tingkat penghasilan dengan kriminalitas. Ambiguitas akan hasil ini kemungkinan disebabkan fakta bahwa penghasilan tidak hanya didapatkan dari pekerjaan legal, tapi juga pekerjaan ilegal yang berpeluang menghasilkan penghasilan lebih. Soal pendapatan, Beauchamp \& Chan (2014) berpendapat bahwa pekerja yang dipengaruhi perubahan upah minimum cenderung melakukan kejahatan, menganggur bahkan kehilangan pekerjaan.

Samarnya antara efek pendapatan terhadap kriminalitas dapat dijelaskan penelitian oleh Ponsaers, Shapland, \& Williams (2008) yang menemukan bagaimana tindak property crime dengan sektor informal saling mengaburkan. Artinya sektor pekerjaan informal lebih beresiko terlibat dalam kriminal. Keduanya adalah hal yang terpisah namun saling menutupi dengan cara yang berbeda-beda. Defenisi informal yang lekat dengan sembunyi-sembunyi, wilayah abu-abu dan tidak transparan lekat dengan kriminalisasi. Misalnya adalah nilai tambah, kontribusi terhadap keamanan sosial, masalah perburuhan, dan pajak menjadi salah satu indikator sektor informal lekat dengan kriminalisasi, khususnya property crime (Ponsaers et al., 2008).

Sementara itu di Indonesia, variabel tingkat upah berpengaruh negatif dan signifikan terhadap tingkat kriminalitas di Indonesia. Dimana Upah Minimum Kabupaten/ Kota (UMK) yang rendah mengakibatkan tingginya angka kriminalitas disebuah kabupaten/ kota tersebut (Hardianto, 2009). Upah minimum mempunyai hubungan yang negatif terhadap kejahatan dengan kekerasan, kejahatan properti, dan total kejahatan. Semakin rendah upah minimum akan berdampak negatif terhadap kekerasan dan kejahatan (Beauchamp \& Chan, 2014). Upah sebagai insentif yang layak, berpengaruh signifikan terhadap turunnya angka kriminalitas pencurian di Inggris dan Wales (Eide, Rubin, \& Shepherd, 2006). Pendapatan memiliki efek negatif saat pelaku mempertimbangkan perbandingan ekspektasi keuntungan sektor ilegal dan legal, sebagaimana telah dijelaskan dalam model rasional kejahatan (Miller, 2009).

Setelah faktor pendidikan, pekerjaan dan pendapatan, tingkat kemiskinan terhadap tindak kriminalitas jelas perlu digarisbawahi. Pengaruh kemiskinan dalam kriminalitas tidak ditemukan pada penelitian yang dilakukan oleh Erizal (2016). Penelitian Erizal tersebut mengemukakan bahwa persentase penduduk miskin tidak berpengaruh signifikan terhadap tingkat kriminalitas di 27 provinsi Indonesia (Tahun 2011-2015). Penelitian serupa oleh Sulistyo (2014) yang dilakukan pada periode sebelumnya, yaitu antara Tahun 2007-2011 di 30 provinsi, menunjukkan hal berbeda soal kemiskinan dan kriminalitas. Menurutnya, persentase penduduk miskin yang tinggi akan meningkatkan tingkat kriminalitas di Indonesia. Perbedaan hasil penelitian dengan periode penelitian yang berbeda dengan analisis regresi data panel ini, menguatkan dugaan penelitian yang dilakukan oleh Khan et al., (2015). Penelitian mereka di Pakistan mendapatkan hasil pada jangka panjang kemiskinan memiliki hubungan positif dengan kriminalitas sementara pada jangka pendek berhubungan negatif.

Terkait demografi, faktor gender dan usia, menunjukkan kriminalitas sebagai aktivitas yang didominasi laki-laki berusia muda (Witte \& Witt, 2000). Tingkat perilaku kriminalitas meningkat signifikan pada usia remaja. Kondisi ini erat kaitannya dengan fenomena Not in Education, Employment or Training (NEET). Pendapat Williamson dalam Grover (2008) perlu menjadi sorotan, yaitu di Britania Raya digambarkan NEET adalah istilah yang menggambarkan orang-orang muda yang menggeser kesetimbangan struktur sosial karena NEET didominasi penduduk usia produktif (83 persen laki-laki dan 63 persen perempuan) yang tidak bekerja dan tidak berniat untuk bekerja.

Faktor keluarga juga diyakini menentukan kecenderungan perilaku kriminal. Mereka yang tumbuh dengan struktur keluarga yang tidak lengkap memungkinkan melakukan tindak kejahatan (Antecol \& Bedard, 2007). Dua kondisi tersebut menunjukkan adanya hubungan yang bersifat kausal. Bahkan, dalam penelitian tersebut Antecol \& Bedard (2007) membuktikan bahwa pemuda yang dibesarkan oleh orang tua tunggal cenderung berprestasi buruk disekolah dan terlibat dengan perilaku "menyimpang". Banyak penelitian lintas ilmu juga menemukan bahwa proporsi keluarga yang dikepalai oleh orang tua tunggal dikaitkan dengan lebih banyak kejahatan. Faktanya, masalah keluarga adalah gangguan terkuat kesembilan dari sejumlah prediktor kejahatan (O'Flaherty \& Sethi, 2014).

Berdasarkan variabel pengaruh lingkungan, baik lingkungan keluarga dan lingkungan diluar keluarga, pengaruhnya lebih besar untuk jenis property crime. Untuk jenis violent crime, baik pengaruh keluarga dan lingkungan tidak menjadi determinan mendorong pelaku kejahatan jenis ini. Kondisi tersebut selaras dengan penelitian yang dilakukan oleh Munyo \& Rossi pada Tahun 2013; dimana disimpulkan bahwa adanya rasa frustrasi mendorong emosi pelakunya untuk berbuat violent crime dan euforia sebagai faktor yang menekan emosi seseorang untuk tidak berbuat kriminal, khususnya violent crime. Penelitian di Uruguay tersebut dilakukan 
terhadap pendukung sepakbola klub Nacional dan Penarol. Dimana, tindak violent crime akan lebih besar saat pendukung sepakbola salah satu klub tersebut mengalami kekalahan. Sebaliknya, euforia setelah kemenangan klub kesayangan mereka mereduksi tingkat violent crime, meski tidak menjamin menekan jenis tindak kriminal lainnya. Sesederhana itu, frustrasi atau euforia sebuah lingkungan mempengaruhi perilaku individunya.

Ketahanan sosial lingkungan dengan didukung infrastruktur yang baik juga mempengaruhi kecenderung tindak kriminalitas (Breetzke \& Pearson, 2015). Temuan tersebut adalah kondisi di Selandia Baru. Dukungan infrastruktur tersebut terkait tempat-tempat spesifik yang perlu perhatian khusus untuk kemungkinan tindak kriminal. Ketahanan lingkungan menurut (Breetzke \& Pearson, 2015) mempengaruhi sebab akibat kriminalitas. Baik dari sisi pelaku atau korban. Ketahanan lingkungan akan mempengaruhi ketahanan individu.

\section{Kesimpulan}

Penulisan ini bermula dari kajian faktor yang mempengaruhi tindak kriminal. Pendekatan sosial ekonomi digunakan untuk mengetahui seperti apa kondisi sosial ekonomi yang mendorong seseorang untuk berbuat kriminal. Dalam sudut pandang kriminologi, perilaku kriminalitas sangatlah kompleks. Tak semudah menebak bahwa orang yang kesulitan ekonomi akan melakukan pencurian. Banyak faktor dan latar belakang dari si pelaku yang perlu diungkap sehingga diketahui karateristiknya. Tujuannya, agar masyarakat dengan karateristik serupa bisa ditekan probabilitas atau diminimalisir kecenderungannya untuk berbuat kriminal atau dikriminalisasi.

Berdasarkan studi literatur terungkap bahwa faktor pendidikan dan keterampilan, pendapatan, pekerjaan, kemiskinan, usia, keluarga dan lingkungan memiliki pengaruh berbeda terhadap perilaku kriminalitas. Secara empiris memiliki efek berbeda pada masing-masing individu. Faktor-faktor yang diulas diatas, pada kondisi tertentu diketahui mampu mencegah tindak kriminalitas. Perbaikan terhadap salah satu faktor tersebut belum akan mengurangi peluang individu melakukan tindak kriminalitas. Beranjak dari kondisi tersebut, perlu sejumlah kebijakan spesifik. Meliputi kebijakan yang harus dilakukan semua pihak untuk mereduksi tingkat kriminalitas baik untuk tidak menjadi pelaku atau korban. Kebijakan kedua meliputi tindakan rehabilitasi terhadap pelaku tindak kriminal mulai dari proses hukum hingga ia bebas dan terintegrasi dengan masyarakat dan lingkungannya.

\section{Daftar Pustaka}

Abdulsyani. (1994). Sosiologi (Skematik, Teori dan Terapan). Jakarta: Bumi Aksara.

Antecol, H., \& Bedard, K. (2007). Does single parenthood increase the probability of teenage promiscuity, substance use, and crime?. Journal of Population Economics, Vol. 20(1), pp.55-71.

Atmasasmita, R., \& Wibowo, K. (2016). Analisis Ekonomi Mikro tentang Hukum Pidana Indonesia. Jakarta: Kencana.

BPS (Badan Pusat Statistik). (2018). Statistik Kriminalitas 2017. Jakarta: BPS.

Beauchamp, A., \& Chan, S. (2014). The Minimum Wage and Crime. The B.E. Journal of Economic Analysis \& Policy, Vol. 14, No. 3, pp.1-23.

Breetzke, G. D., \& Pearson, A. L. (2015). Socially disorganized yet safe: Understanding resilience to crime in neighborhoods in New Zealand. Journal of Criminal Justice, Vol. 43, pp.444-452.

Conway, E. (2009). 50 Economic Ideas You Really Need to Know. London: Quercus Publishing Ltd.

Durrant, R., \& Ward, T. (2015). Evolutionary Criminology Toward A Comprehensive Explanation of Crime ( $1^{\text {st }}$ edition). London, UK: Academic Press.

Eide, E., Rubin, P. H., \& Shepherd, J. M. (2006). Economic and Crime :Foundation and Trends in Microeconomics. Hanover, MA, US: Now Publishers Inc.

Erizal, M. E. (2016). Analisis Faktor-Faktor yang Mempengaruhi "Crime Rate" di Indonesia Tahun 2011-2015. Tesis, Magister PPn Fakultas Ekonomi Universitas Andalas, Padang.

Gillani, S. Y., Rehman, H. U., \& Gil, A. R. (2009). Unemployment, Poverty, Inflation and Crime Nexus: Cointegration and Causality Analysis of Pakistan. Pakistan Economic and Social Review, Vol. 47, No. 1 (Summer 2009), pp.79-98.

Goulas, E., \& Zervoyianni, A. (2015). Economic growth and crime: Is there an asymmetric relationship?. Economic Modelling, Vol. 49 (September 2015), pp.286-295.

Grover, C. (2008). Crime and Inequality. Portland: Willan Publishing.

Hardianto, F. N. (2009). Analisis Faktor-Faktor yang Mempengaruhi Tingkat Kriminalitas di Indonesia dari Pendekatan Ekonomi. Bina Ekonomi, Vol. 13, No. 2 (Agustus 2009), pp.28-41.

Jonck, P., Goujon, A., Testa, M. R., \& Kandala, J. (2015). Education and crime engagement in South Africa: A national and provincial perspective. International Journal of Educational Development, Vol. 45 (November 2015), pp.141151. 
Khan, N., Ahmed, J., Nawaz, M., \& Zaman, K. (2015). The Socio-Economic Determinants of Crime in Pakistan: New Evidence on an Old Debate. Arab Economics and Business Journal, Vol. 10, pp.7381.

Levitt, S. D., \& Dubner, S. J. (2005). Freakonomics: A Rogue Economist Explores the Hidden Side of Everything. NY: Harper Collins Publisher Inc.

Lochner, L. (2004). Education, Work, and Crime: A Human Capital Approach. International Economic Review, Vol. 45, No. 3 (Agustus 2004), pp.811843.

Lochner, L., \& Moretti, E. (2004). The Effect of Education on Crime: Evidence from Prison Inmates, Arrests, and Self-Report. The American Economic Review, Vol. 3, No. 1 (March 2004), pp.155-189.

Miller, J. M. (2009). 21th Century Criminology: A Reference Handbook. Thousand Oak (CA): SAGE Publication, Inc.

Mohammed, H., \& Mohamed, W.A.W. (2015). Reducing Recidivism Rates through Vocational Education and Training. Social and Behavioral Sciences, Vol. 204, pp.272-276.

Munyo, I., \& Rossi, M. A. (2013). Frustration, euphoria, and violent crime. Journal of Economic Behavior \& Organization, Vol. 89, pp.136-142.

Nettler, Gwyn. (1984). Exploring Crime. NY: McGrawHill.

O'Flaherty, B., \& Sethi, R. (2014). Urban Crime. Tersedia pada http://real.wharton.upenn.edu/ duranton/Duranto n_Papers/Handbook/Urban_crime.pdf [Diakses pada 11 Februari 2019].

Paramita, Rahadian P. (2018). Interval Kejadian Kejahatan di Indonesia Memburuk. Beritagar.id [internet], 04 Januari 2018. Dapat diakses pada https://beritagar.id/artikel/berita/interval-kejadiankejahatan-di-indonesia-memburuk [Diakses pada 10 Februari 2019].

Ponsaers, P., Shapland, J., \& Williams, C.C. (2008). Does the informal economy link to organised crime? International Journal of Social Economics, Vol. 35, No. 9, pp.644-650.

Posner, R. A. (1992). Economic Analysis of Law (4th ed.). Chicago: Little Brown and Company.

Ramadhan, C. (2016). Pengantar Analisis Ekonomi dalam Kebijakan Pidana di Indonesia. Jakarta: Institute for Criminal Justice Reform (ICJR) dan MaPPI FH UI.

Santoso, T., \& Zulfa, E. A. (2016). Kriminologi. Jakarta: PT. Raja Grafindo Persada.

Sulistyo, H. (2014). Analisis Faktor-Faktor yang Mempengaruhi Tingkat Kriminalitas di Indonesia Tahun 2007-2011. Tesis, Magister Ekonomika Pembangunan Fakultas Ekonomika dan Bisnis UGM, DI Yogyakarta.

Sullivan, A. O. (2009). Urban Economics. New York: McGraw-Hill/Irwin.
Witte, A. D., \& Witt, R. (2000). Crime Causation: Economic Theories. Tersedia pada https://www.surrey.ac.uk/economics/files/apapers pdf/ECON\%2003-00.pdf [Diakses pada 4 maret 2019]. 